\title{
ANALYSES AND CONSERVATION STRATEGIES OF INDIGENOUS ILOKANO FOLKSONGS IN NORTHWESTERN CAGAYAN, PHILIPPINES
}

\author{
Allan O. de la Cruz ${ }^{1}$
}

Review scientific paper

Cagayan State University-Sanchez Mira Campus, Sanchez Mira, Cagayan, Philippines

Received: 2018/9/1

Accepted: 2018/12/15

\begin{abstract}
The study collected and analyzed the content, theme, and virtues nested in the indigenous Ilocano songs in the Northwestern part of Cagayan province, Philippines. These folksongs are expressions of Ilokanos' thoughts, feelings and emotions as shown in the folksongs on love for humanity and the natural world. The themes are focused on being proud, happy and thankful for the quality of life they have, for any beautiful thing, for the love of family, and for the gift of nature. The dominant virtues traced include faithfulness, idealism, optimism, industry, humility, unity, pride, love and respect. Preservation and conservation of these folksongs is possible through collecting and documentation, transforming these songs into various media (printed and electronic), and establishing a folksong museum which could be a Center of Folksong- Knowledge Transmission. Government and the academic community should help support the conservation of authentic Ilokano songs before these shall be forgotten.
\end{abstract}

Keywords: content analysis, Ilocano folksongs, indigenous songs, Northwestern Cagayan, preservation and conservation, translations

\section{INTRODUCTION}

Music is the language of the soul. It is a form of language that has to be continuously communicated to the succeeding generations so as not to lose its intrinsic worth, symbols and forms, as well as its varying meanings (Buenrestro \& Cabbab, 2013).

The International Folk Music Council as cited by $\mathrm{Cu}-$ lig (2012) defined folk music as a musical tradition that has evolved through the process of oral transmission. And because of their inherent qualities, aesthetic or practical, folks have a mass appeal that has survived the test of time; passed from one generation to another. Kranenburg et al. (2007) noted that these were sung by common people during work or social activities. One of their important characteristics is that they are part of oral culture. The melodies and texts are learned by imitation and participation rather than from books.

The early Filipinos had songs of a great variety, expressive of a gamut of human experiences and feelings. The natives sang at almost every occasion- at work, at worship and at play. And all occasions, both trivial and eventful, inspired the spontaneous creation of songs. They had lullabies, street songs, work songs, game songs, victory songs, love songs, and funeral dirges and the like (Baltazar et al., 1981). These folk music are also referred to as FOLKSONGS.

Enriquez (2006) defined folksongs are songs that have been handed down orally through generations. These are sung to a repeated melody and committed to memory from the lips of others.

\footnotetext{
Correspondence to:

Allan O. de la Cruz, Faculty of Teacher Education, Business Administration and Graduate School

Cagayan State University, Sanchez Mira, Cagayan, Region 02, Philippines

Phone: +639069671302

E-mail: aodlc2010@hotmail.com
} 
They embody faith, joy, the varied hopes and odds of life. Ogundokun (2015) added that folksongs like any other forms of orator are transmitted from generation to generation, and they are called tradition. Culig (2012) noted that folksongs are generally simple. They have repetitive melody and rhythm, limited ranges, and scale systems that are germane to or assimilated by their cultures of origin from a prolonged close contact with another culture/s. Their lyrics often relate to daily activities which readily make them part of the everyday lives of people regardless of age. They are mostly participatory and functional like singing games, counting songs, work songs, cradle songs, bathing songs, rice pounding songs, war songs, religious songs and even fun non sense songs.

Traditional music is music of the people. It belongs to people of all levels of music ability. Transmitted orally, one does not need any special vocal training to sing a folk song. Since it is handed down orally, from one generation to another, there is no single "correct" version of the folk tune (Aurelio, 2000).

The folk song, as a form of folk lyric expresses the hopes and aspirations, the people's lifestyles as well as their loves (Ortega). Many of these same songs are still sung by Filipinos today to enlighten the cares of life, to pass the time or to kill boredom.

From the several songs that have come down to us through the centuries, Baltasar et al. (1981) pointed out that those of the highland tribes still sing the songs in the old chanting manner while those of the lowlands already show an influence of Western culture, especially in melody. In the study of Bohlman (1988) as cited by Culig (2012) he discussed the dynamic nature of folksongs brought about by urbanization, and modernization of societies. Thus, now exist notated, arranged, authored, and modernized folk songs.

Hence, for folksongs to preserve their authenticity and for the lines of these songs to continually echo across generations and boundaries, the collection and documentation of these folksongs have to be properly captured and preserved.

Meanwhile, Ilokano or Iloko refers to the people and the chief regional language of Northern Luzon. It is spoken by the group of provinces in the Ilocos Region, Cagayan Valley Region, Central Luzon, and it is the lingua franca of all the mountain provinces of Luzon (www.manoa.hawaii.edu/ilokano/mission. html).

In the Northwestern part of Cagayan province, Philippines, the Ilokanos here had a great number of folksongs. Some are still sung and are well-documented, but there are many which are yet to be collected, documented and preserved. It is imperative that these folksongs are to be recorded before they shall be forgotten and affected by modernization, cultural diffusion or intermarriage with other tribes. Moreover, the collection of such is in consonance to the Harmonized National Research and Development Agenda (HNRDA) of the Department of Science and Technology (DOST). The collection of these folksongs fall on the Documentation of Indigenous Knowledge, and Music in Indigenous Filipino Expressive Culture strands of the Inclusive Nation-building-ATIN program (Ang Tining Natin) Program of the National Integrated Basic Research Agenda (NIBRA) Research and Development area of the department ( DOST HNRDA 2017-2022).

The collection of these Ilokano folk music is also in line with the general provision of the Philippine Constitution, Article XIV, Section 14, which states that the Senate shall foster the preservation, enrichment, and dynamic evolution of a Filipino culture. Believing that the culture of a group of people is considered as their wealth, the richness of their culture must be given due recognition. Through the collection, preservation, and study on these folksongs, culture pride would be developed among the Ilokanos.

Likewise, the collection of these folksongs could become rich and effective educational resources for both the instructor and the students in providing them a body of readings for the subject Literature of the Philippines.

There have been studies made on folklore in general in the different provinces in the country. However, for the folksongs in particular, in Northwestern part of Cagayan, Philippines, these folksongs have yet to be given greater attention. This study takes concern on documenting, translating to English language the Ilokano folksongs, and designing a program that would protect and conserve the interesting lore preserved in this land.

\section{OBJECTIVES OF THE STUDY}

The study generally aimed to collect the Ilokano folksongs sung in the Northwestern part of Cagayan, Philippines. Specifically, the paper intended to identify the content and theme of these folksongs; to trace the virtues present in them, and to design a preservation and conservation strategem for these Ilokano Folksongs. 


\section{METHODS}

This is a qualitative study that used documentary and content analysis of the folksongs sung in the Ilokano speaking community in the Northwestern part of Cagayan, Philippines. Personal interview was used in gathering the data for analysis. The folksongs recited/sung/explained by the folks were noted down/ recorded with the use of cell phone recorder. The study was conducted in the towns of Sta. Praxedes, Claveria, Sanchez Mira, Pamplona, Abulug and Ballesteros from January-December 2017. These predominantly Ilokano speaking municipalities in the second district of Cagayan province were located at the Nortwestern part of Cagayan, Region 02, Philippines.

Purposive random sampling was employed to select the senior citizens with knowledge on folksongs and retired professionals with inclination to music to be the key informants. An interview guide was constructed. Informed consent was also prepared. The informants were given the option to write down all the Ilokano folksongs they know on a sheet of paper, or they could recite or sing the song. The researcher took down notes and at the same time recorded the data/lyrics/wordings that come directly from the mouth of these informants. The researcher collected 23 Ilokano folksongs. Folksongs with translations and interpretations readily available to be downloaded from the internet were not included in the study. In processing the data, the researcher transcribed the recorded information, and classified the materials. Also, the researcher tried translating them into suitable English language. In the translation of the Ilokano folksongs to English, the researcher used Eugene Nida's translation theory that since there is no such thing as "identical equivalents", and what one seeks to do in translating is to find the "closest natural equivalent", both formal equivalence and dynamic equivalence were adopted. Formal equivalence focuses on the need to pay attention to the form and content contained in the message, while dynamic equivalence focuses on the message received by the audience.

In the process of finalizing the text of the collected Ilokano folksongs and of the translated English equivalents, knowledgeable music enthusiasts evaluated the accuracy of the text and English language and literature teachers were requested to assess the correctness of the text's translation to English.

Analysis through coding was made to reveal the content, theme and virtues on the folksongs. An induc- tive coding process was useful in determining categories (Le Compte and Schensul, 1999). With that, the researcher used an inductive analysis strategy to generate descriptive categories from the data. This strategy was used to identify the salient themes within the data. In the coding, incidents, the smallest unit of information in a text was looked into first, then the identified incidents were given codes to analyze the data. With this, a preservation and conservation program was designed for this purpose.

\section{RESULTS AND DISCUSSION}

\section{Content Analysis, Thematic Evaluation and Vir- tue Search of the Ilokano Folksongs}

The content of the songs as reflected from the lyrics are of diverse ideas. The Ilokano folksongs gathered in the Northwestern part of Cagayan are classified into seven categories: 1)songs of the heart (a) courtship and (b) broken relationships, 2)songs on the joy/ importance of having a mother, 3 ) songs on the life of a farmer, 4) songs about idealism and wishful dreamer of an Ilokano, 5) songs on admiration to beautiful Ilokano ladies, 6) songs about nature/natural world, and 7) non-sensical song. Jan (1998) in his study pointed out four thematic content like paddy works, healing, entertainment and children games. Also, in his study, he lamented that only a small group of the traditional villagers can sing these songs and these songs seemed to be unknown to the youth.

In the study of Culig (2012) on the content analysis of Asian-Pacific Folksongs, she identified 16 thematic contents. Some of the classifications included in her study which were also the same thematic contents found in the Ilokano folksongs are natural world, home and family, friendship/love, worksongs and nonsense songs. On the other hand, the content of the folksongs in the study of Haruna (1998) about the Bura folksongs, their content are all-encompassing. Those folksongs express Bura people's sociocultural values, religious beliefs and experiences. Some songs abuse or satirize individuals or groups of people. Other songs treat subjects such as love, marriage, death, kinship, religion or politics. As regards the virtues traced in the folksongs, the Ilokanos' traits are reflected in these folksongs. As Yabes (1936) described in his article, the Ilokano character and culture is simple in life, heart, and taste, humble, religious, industrious and thrifty. 
He also gave this descriptions of an Ilokano as utility man, one who interprets life in terms of usefulness; Ilocano girls as reserved, conservative and orthodox; they hide their emotions, represses their feelings, a man of action. Also, he noted that Ilokanos think as they work; their patience, endurance and ability to stick and concentrate on anything they do are the secret of their success. Ilokanos go anywhere, they penetrate into strange territory and get along well and make friends with everybody. The folksongs of Ilocandia as a whole are more expressive of joy, vigor, activity and optimism. They are expressive of the true spirit of Ilocanos. That despite their centuries of subjection, they have not lost the vigorous and optimistic spirit of their forebears (Yabes, 1936).

In the study of Yalcinkaya (2015) among the values present in the songs in the elementary books, there were 19 virtues identified, and some of which are virtues also traced in the Ilokano folksongs like that of love, respect, self-esteem, diligence, tolerance, loyalty, and solidarity. As regards the unifying ideas of the 23 folksongs under study, the themes focused on being proud, happy and thankful for the quality of life they have, for the love of beauty inside and out and the many faces of love, for the love of family, mother and children, and for the gift of nature.

A more vivid description on the 23 folksongs under study is found below. It is noted that the English translations of the Ilokano folksongs are in the full blown research, and were not included in this text.

\section{Folksong \#1: Bambantay, Turturud (Mountains and} Hills)

The song tells the simplicity of life and it boasts and encourages one to visit the bounty in mountains and hills where they live.

Theme : Be proud and thankful to the quality of life you have.

Virtue: Pride on what one has.

\section{Folksong \# 2: Dagiti Mulak (My Plants)}

The folksong illustrates the life of a farmer that at times, there is a low produce because of unforeseen occurrences.

Theme : Life is full of challenges.

Virtue: Industry/Steadfastness- Ilokano farmers remain strong in spite of obstacles.

\section{Folksong \# 3: Denggem Ading (Listen My Dear)}

The song depicts $\mathrm{s}$ the love of a man that is real, that his love for a woman is eternal.

Theme : Everything that a person in love sees is beautiful.
Virtue: Faithfulness-Ilokanos pursues the love of a woman who is sometimes fickle-minded.

\section{Folksong \# 4: Di Kan Agsangsangit (Cry No More)}

The song talks about a man appeasing a woman cyring so hard because of a broken relationship.

Theme: Do not cry over a broken relationship.

Virtue: Optimism- if one door closes, another opens.

\section{Folksong \# 5: Dikanton Malipatan (I will Never Forget} You)

The song tells that true love knows no boundaries, no ending. There is forever that death cannot even deter.

Theme: True love means forever.

Virtue: Faithfulness- Ilokanos offer an everlasting love.

Folksong \# 6: Diro ni Ayat (Sweetness of Love)

The song talks about lovers who agreed to be together and decided not to separate until the end of time.

Theme: We need a companion to lean on.

Virtue: Faithfulness-Ilokanos are sweet lovers.

\section{Folksong \# 7: Dunggiar (Dunggiar)}

The song illuminates Dunggiar, who died in search for a ladylove.

Theme: True love is hard to find.

Value: Perseverance- An Ilokano is ready to die in the name of love.

\section{Folksong \# 8: Igid diay Baybay (By the Seashore)}

The song tells about the plans of the man to his ladylove to go by the seashore, sing their love song, and feel the complete happiness, peace and gratification in the area.

Theme: There is joy in the presence of nature.

Virtue: Idealism- Ilocano lovers make sweet promises (both possible and the impossible).

\section{Folksong \# 9: Intan Neneng (Let's Go My Dear)}

The folksong speaks of the sweet-tongued nature of an Ilokano lover- going to the moon, and not loving anybody else but the girl of his love.

Theme: Love has many promises.

Virtue: Idealism-Ilokano suitors dare to dream big.

Folksong \# 10: Inton Agkasarak (When I get Married)

The song tells the ideals, wishes and dreams of a girl when she gets married. At times, they would even dream of the impossible dreams.

Theme : Marriage for ladies matter.

Virtue: Idealism- Ilokana woman, too, has great dreams. 
Folksong \# 11: Ipuon ko nga Irugi (I Will Start from the Beginning)

The song talks on the challenges in the life of an orphan.. In the absence of the mother, usually, the eldest takes the responsibilities left by the mother particularly on taking care of his/her siblings.

Theme: Mother gives light to the house.

Virtue: Love. Mother's love and care is of importance to children.

\section{Folksong \# 12: Katuday (Katuday)}

This song tells about a man wishing the impossiblethat if ever he would be a ring, he would always cling to the fingers of his lady. If she would be a pineapple, he would pick her although still unripe and keep her until she ripens in his heart.

Theme: The figments of imagination are sometimes stronger than life's realities.

Value: Idealism- An Ilokano lover is a dreamer.

\section{Folksong \# 13: Kuna ni Nanang (Mother's Advise)}

The song reminds us the importance on the role of mothers in our lives. That without them, life will lose its direction. It also emphasizes that the love of a stepmother does not equate a mother's love.

Theme: Mother's love is beyond compare.

Virtue: Love- Children long for the love of a mother.

\section{Folksong \# 14: Lubi-lubi (Pounding Activity)}

The song talks about the introverted lady all through the year. She refuses to go out for a "lubi-lubi" (banana or cassava pounding activity of young boys and girls) because of the presence of individuals in the place.

Theme: Ladies are cautious.

Virtue: Conservativeness- Ilokanas are typically shy.

\section{Folksong \# 15: Maymaysa ti Pusok(One Heart)}

This song is about a lover persuading a girl who seem to doubt his love. That is why he promises that his one heart is just for her ladylove.

Theme: Girls are hard to get.

Virtue: Faithfulness- Ilokano suitors are one man-one heart.

Folksong \# 16: Nagsabong ken Ayat (Flowered with Love)

The song recounts a love that has never bloomed to reality because of the man's infidelity. As the woman recalls her long lost love, she cannot help but faint in her disappointment.

Theme: Love sometimes is unfair that it is not fitly reciprocated.

Virtue: Fidelity-Loyalty to a partner keeps the relationship longer.

Folksong \# 17: Nagsaway a Pintas mo (Unfading Beauty)

The song tells about a lady who seems to monopolize all the beauty on earth- one with curly hair, sparkling white teeth, with star-like dimples and eyebrows like the rainbow.

Theme: Beauty draws joy, curiosity and attention.

Virtue: Beauty- Ilokanos adore beautiful ladies

\section{Folksong \#18: Ni Mannalon (The Farmer)}

The folksong talks about farming as one of the major sources of living of the Ilokanos. It shows the importance, simplicity and the laborious work of a farmer. He may be poor, but he provides the basic needs especially, rice, fruits, vegetables and other products that are important in our daily lives.

Theme: Work and earn for a living.

Virtue: Industry- Ilocano farmers work hard for the community.

\section{Folksong \# 19: Ni Nanang Ko (My Mother)}

The song narrates the love, care and concern of a mother to her son/daughter that is immeasurable. In the song, the child also tells the birth of his/her mother in summer time when trees and flowers are in bloom. Theme: Mother knows best.

Virtue: Love- The love of a mother is beyond compare.

Folksong \# 20: Papanam Kulibangbang (Where are you Heading butterfly?

This song talks about a lady, who was referred to as butterfly, who went on to let her handkerchief be repaired. The song also advises young men to choose a red-lip lady for that woman is a sure hit.

Theme: Choose a person to live with upon the advice of the old.

Virtue: Beauty- Ilokanas are simply beautiful.

Folksong \#21: Tarong, Kamatis, Parya (Eggplant, Tomato, Bittergourd)

The song talks about the three vegetables which prides oneself on a particular quality. One boasts about its being delicious. Another answered back that dinengdeng (native Ilokano cuisine) is at its best with its presence. Theme: Do not boast as if you are best.

Virtue: Humility- Be proud of what you have, but live still with humility. 
Folksong \#22: Ti Ayat ti Maysa nga Ubing (The Love of a Young)

The song compares the love of young that is sweet and fresh with the love of the old that is bitter and upsetting. The old man is advised to look for a widow and to forget the love of a young especially if the girl has already found her THE ONE.

Theme: It is more comfortable to live with someone of your age.

Virtue: Beauty-Beautiful and young ladies are adored.

\section{Folksong \# 23: Uppat a Pato (Four Ducks)}

The song talks about the happy, cohesive and unrestricted life of ducks as observed by the persona.

Theme: Free yet united creatures are happy beings.

Virtue: Unity-Happiness in being together.

\section{Preservation and Conservation of the Ilokano Folk- songs}

In terms of its preservation and conservation, the government and the academe in the Ilokano speaking communities should work hand in hand for the establishment of a folksong museum, which could also be an institute of folksong-knowledge transmission. A particular body in the academic community should control its implementation. The support of the community is also needed because the success in the transmission of these folk songs to the next generations is dependent on collaboration of the academic community and the townsfolk lead by the community leaders.

The government funding agencies and the research and development arm of learning institutions should support a research grant to researchers who pursue Ilokano folksong studies.

In schools and in the community, competitions on folk singing in solo, pairs or in a group should be initiated. They could also set a month in a school year where different schools/colleges or different barangays in the town meet and compete for folk song interpretation. Although folk singing is integrated in the Philippine Literature classes and it is a part of the curriculum of all degree and non-degree courses in tertiary education, this is not enough.

These folksongs should also be transformed into several varieties of print and electronic media for easier access. Song books on these Ilokano folksongs are to be made. Also, folk songs in volumes of CDs/DVDs or a series of musical-radio programs should be produced. Recorded Ilokano songs sung by children or adults be uploaded in the internet or you tube for easier access and preservation on these songs.

These are important measures to conserve and preserve these pieces of local heritage for the future generation. Tejero (2008) noted in her study that the Philippine traditional music is undoubtedly a very important part of our cultural heritage; however, it is endangered of extinction. Hence, the production of music materials (workbooks, librettos for musical plays, ethnic-based compositions, tapes, CDs, VCDs and DVDs were developed in her research.

Techie and Tetteh (2016) in their study emphasized that it is the extinction problem occurring from change in taste and preference of the youth in outmoded oral art forms like the S'wamba folksongs that has engineered a study to recreate awareness of the benefits of importance of orature. They added that "There is a need to preserve these similar art form and songs for posterity. These folk songs and other traditional oral forms shape the history and identity of an indigenous community." Legall (2008) pointed out in her study that the preservation of traditional knowledge involves the documentation of traditional knowledge via the provision of registers, inventories, and databases. Also, preservation involves the promotion of traditional knowledge through educational initiatives.

Also, the idea that could be noted was the one of Buenrostro and Cabbab (2013) who noted that it is our responsibility to preserve the materials of cultural heritage. It is important to relive and capture the remains of the Filipino classical music, so that this music era, genre and forms will forever live. This tangible collection of music heritage has cultural, historical and symbolic value-a real asset of the country.

\section{CONCLUSION AND RECOMMENDATIONS}

The Ilokano folksongs were expressions of their thoughts, feelings and emotions. The folksongs reflect the way of Cagayano's life that is full of ideals, beliefs and aspirations which are significant to the development of their moral and social values. Support from the government and the academic community is needed to realize the establishment of a folksong museum to preserve and conserve these songs from our forebears before these shall be forgotten.

It is recommended that further research in the gathering of unpublished original data on folksong for its preservation and conservation shall be funded. The Ilokano folksongs should be adopted as supplementary materials for learners in the Ilokano speaking communities in elementary, secondary and tertiary levels. 
When all folksongs in Cagayan shall have been gathered, translated and analyzed, they should be published in a book form and circulated within and outside the province. A study should also be made focusing on putting musical notation on these folksongs, be sung by Ilokano singers, be recorded in CDs to penetrate the national market and the ASEAN Community. The same study should be conducted in other towns of Cagayan and other Ilokano speaking provinces to have a more comprehensive listing of indigenous Ilokano folksong and to strengthen the moral values of the people. A functional Center for Ilokano Folksong knowledge transmission be instituted in the academe to lead the safe keeping and preserving of this lore.

\section{REFERENCES}

Aurelio, M. F. (2000). The Iluko Traditional Chant in the Life Cycle. Retrived 31 October 2017, http://ejournals.ph/ article.php? $1 \mathrm{~d}=9288$

Baltazar, S. et.al. (1981). Philippine Literature Past and Present. Quezon City: Katha Publishing Co., Inc.

Buenrestro, I. S. \& Cabbab, J.A. (2013). Reliving the Filipino Classical Music Heritage: Preservation and Restoration of Philippine Art Music Manuscripts of the University of the Philippines- Diliman College of Music. Retrieved 30 May 2017, http://library ifla. org/56/7/095/-buenristri.em.pdf

Culig, E. C. (2012). A Content analysis of Asian-Pacific Folksongs in Elementary Music Textbooks from 1967 to 2008. Music Education Graduate Theses and Dissertation.6. Retrieved 12 September 2017, http://scholar. colorado.edu/mued gradetds $/ 6$

Department of Science and Technology. Harmonized National Research and Development Agenda 2017-2022. Retrieved 7 March 2017, dost.gov.h/phocadownload/ Downloads/Journals/Harmonized_National_RD_ Agenda_2017-2022_final_v2.pdf

Enriquez, D. C. (2006). Philippine Literature: A regional approach. Mandaluyong City, Philippines: National Book Store

Haruna, Z. K. (1998). Bura Folksongs: An analysis of their types, occasions, themes, techniques and functions. Retrieved 10 September 2017, http://research.library.mun. $\mathrm{ca} / 1171 /$

Ilokano Language and Literature Program. Retrieved 14 August 2017, www.manoa.hawaii. edu/ilokano/mission.html

Jan, C. C. (1998). Malay Traditional Folk Songs in Ulu Tembeling: It's Potential for a Comprehensive Study. Pertanika Journal. Social Science and Humanities. Retrieved 12 September 2017, www. psasir.upm.edu.my/3201/1/ Malay_Traditional_Folk_Songs_In_OIu_Tembeling. pdf
Kranenburg, P. et. al. (2007). Towards Integration of Music Information Retrieval and Folk Song Research. Retrieved 25 September 2017, http://webdoc.sub.gwdg.de/ebook/erien/ah/UU-CS/2007-016.pdf

Le Compte, M. \& Schensul, J. (1999). Analyzing Qualitative Data. Retrieved from http://www.bwgriffin.com/gsu/ courses/edur9131/readings/LeCompte_analyzing qualitative_data_(suitable_open_ended).pdf

Legall, S. (2008). Protecting Traditional knowledge and Folklore/Traditional Culture Expressions Policy and Legal Challenges for Carribean Countries. Retrieved 15 August 2017, http://www.wipo.int/edocs/mdocs/tk/en/ wipo_grtk_kin_08/wipo_grtk_kin_08_presentation02. pdf

Nida, E. A. Dynamic and Formal Equivalence. Retrieved 25 April 2017, https://en. Wikipedia.org/wiki/Dynamic and_formal_equivalence

Ogundokun, $\overline{\text { S. A. A }}(2 \overline{0} 15)$. The Role of Orature in African SocioCultural Space." International Journal of English and literature. Retrieved 12 September 2017, https://www. researchgate.net/publication/283505661_The_role of orature in African socio-cultural space

Ortega, C.G. ( ). The literary Forms in Philippine Literature. Retrieved 12 September 2017, https://aboutphilippines. $\mathrm{ph} /$ files/The-Literary-Forms-in-Philippine-Literature1.pdf

Techie, C. D. \& Tetteh, S.A. ( 2016). The Importance of Orature in the Life of a Community: An Appreciation of the Role of the S'wamba Folksongs in the Edina Traditional Area, Ghana. Asian Journal of Multidisciplinary Studies. Vol4, Issue 5, April 2016. Retrieved 04 August 2017

Tejero, H. S. (2008). Music Translation: Giving Back to the People their Rich Musical Heritage. JPAIR Multidisciplinary Journal. Vol 2, January 2009. Retrieved 20 August 2017 from https://ejournals.ph/article.php?1d=7403

Yabes, L. Y. (1936). A Brief Survey of iloko Literature from the beginning to its Present Development, with Bibliography of works pertaining to the Iloko People and their Language. Retrieved 3 May 2017, https: //quod.lib. unich.edu/p/philamer

Yalcinkaya, B. (2015). Content Analysis of songs in elementary Music Textbooks in accordance with Values Education in Turkey. Retrieved 15 September 2017, http://www. academicjournals.org/journal/ERR/article-full-textpdf/78848BF52386 